\title{
The association between serum vitamin $D$ and body composition in South African HIV-infected women
}

\begin{tabular}{|c|c|}
\hline \multicolumn{2}{|c|}{$\begin{array}{l}\text { Authors: } \\
\text { Samuel Mwango } \\
\text { Janet Carboo }{ }^{1} \\
\text { Christa Ellis }{ }^{1} \\
\text { Marike Cockeran } \\
\text { Carina M.C. Mels } \\
\text { Herculina S. Kruger }\end{array}$} \\
\hline $\begin{array}{l}\text { Affiliations: } \\
{ }^{1} \text { Centre of Exc } \\
\text { Nutrition, Facl } \\
\text { Sciences, Nort } \\
\text { University, Pot } \\
\text { South Africa }\end{array}$ & $\begin{array}{l}\text { ellence for } \\
\text { chlty of Health } \\
\text { h-West } \\
\text { tchefstroom, }\end{array}$ \\
\hline $\begin{array}{l}{ }^{2} \text { Statistics Con } \\
\text { Service, Facult } \\
\text { Sciences, Nort } \\
\text { University, Pot } \\
\text { South Africa }\end{array}$ & $\begin{array}{l}\text { sultation } \\
\text { y of Natural } \\
\text { h-West } \\
\text { thefstroom, }\end{array}$ \\
\hline $\begin{array}{l}{ }^{3} \text { Department } \\
\text { Faculty of Hea } \\
\text { North-West U } \\
\text { Potchefstroom }\end{array}$ & $\begin{array}{l}\text { f Physiology, } \\
\text { Ith Sciences, } \\
\text { niversity, } \\
\text {, South Africa }\end{array}$ \\
\hline $\begin{array}{l}{ }^{4} \text { Medical Rese } \\
\text { Hypertension } \\
\text { Cardiovascular } \\
\text { Research Unit, } \\
\text { Health Science } \\
\text { University, Pot } \\
\text { South Africa }\end{array}$ & $\begin{array}{l}\text { arch Council, } \\
\text { and } \\
\text { r Disease } \\
\text { Faculty of } \\
\text { es, North-West } \\
\text { tchefstroom, }\end{array}$ \\
\hline $\begin{array}{l}\text { Correspondin } \\
\text { Herculina Krug } \\
\text { salome.kruger }\end{array}$ & $\begin{array}{l}\text { g author: } \\
\text { ser, } \\
\text { @nwu.ac.za }\end{array}$ \\
\hline $\begin{array}{l}\text { Dates: } \\
\text { Received: } 02 \mathrm{~J} \\
\text { Accepted: } 12 \\
\text { Published: } 30\end{array}$ & $\begin{array}{l}\text { uly } 2021 \\
\text { Aug. } 2021 \\
\text { Sept. } 2021\end{array}$ \\
\hline $\begin{array}{l}\text { How to cite th } \\
\text { Mwango S, Ca } \\
\text { Cockeran M, N } \\
\text { Kruger HS. The } \\
\text { between serur } \\
\text { and body com } \\
\text { South African } \\
\text { women. S Afr } \\
\text { 2021;22(1), a1 } \\
\text { doi.org/10.41 } \\
\text { v22i1.1284 }\end{array}$ & $\begin{array}{l}\text { lis article: } \\
\text { rboo J, Ellis C, } \\
\text { Mels CMC, } \\
\text { association } \\
\text { m vitamin D } \\
\text { position in } \\
\text { HIV-infected } \\
\text { J HIV Med. } \\
\text { 284. https:// } \\
\text { 02/sajhivmed. }\end{array}$ \\
\hline Read online: & \\
\hline 回的回 & $\begin{array}{l}\text { Scan this QR } \\
\text { code with your } \\
\text { smart phone or } \\
\text { mobile device } \\
\text { to read online. }\end{array}$ \\
\hline
\end{tabular}

Background: HIV and antiretroviral therapy (ART) alter vitamin D metabolism, and may be associated with bone loss.

Objectives: The aim of this study was to determine the association between serum 25-hydroxyvitamin D (25(OH)D) and body composition in postmenopausal South African women living with HIV and on ART.

Method: In this 2-year longitudinal study on 120 women conducted in the North West province of South Africa, serum 25(OH)D concentration, bone mineral density (BMD) at three sites, lean mass and percentage of body fat $(\% \mathrm{BF})$ were measured by dual-energy X-ray absorptiometry (DXA). Multivariable linear mixed models were used to assess the association between serum $25(\mathrm{OH}) \mathrm{D}$ and body composition over 2 years. Linear mixed models were also used to determine the longitudinal association between lean mass, \%BF and BMD.

Results: Vitamin D deficiency and insufficiency increased from baseline (10.2\% and 19.5\%) to $11.5 \%$ and $37.5 \%$, respectively, after 2 years. Serum $25(\mathrm{OH}) \mathrm{D}$ decreased significantly, however, with a small effect size of $0.39(P=0.001)$, whilst total BMD (effect size $0.03, P=0.02$ ) and left hip femoral neck (FN) BMD (effect size 0.06, $P=0.0001$ ) had significant small increases, whereas total spine BMD did not change over the 2 years. Serum 25(OH)D had no association with any BMD outcomes. Lean mass had a stronger positive association with total spine and left FN BMD than \%BF.

Conclusion: Serum 25(OH)D was not associated with any BMD outcomes. Maintenance of lean mass could be important in preventing bone loss in this vulnerable group; however, longer follow-up may be necessary to confirm the association.

Keywords: Vitamin D; postmenopausal; adiposity; bone mineral density; Africa; HIV/ AIDS; ART.

\section{Background}

Vitamin D is a pro-hormone primarily known for its role in bone development through calcium and phosphorus homeostasis. ${ }^{1}$ It is acquired from dietary sources that include fish, egg yolk, liver and vitamin D fortified foods; however, cutaneous synthesis of vitamin D contributes to more than $90 \%$ of the requirements. ${ }^{2}$ Epidemiological studies across the world indicate a close association between vitamin D deficiency and chronic diseases, such as bone metabolic disorders, tumours, cardiovascular diseases and diabetes mellitus. ${ }^{3}$ The prevalence rate of vitamin D deficiency worldwide varies between $30 \%$ and $93 \%$, and is a growing public health concern amongst all age categories and ethnic groups. ${ }^{4,5,6}$ Hypovitaminosis D is also a prevalent disorder in low- and middle-income countries. ${ }^{7}$ Durazo-Arvizu et al. ${ }^{8}$ reported a higher prevalence rate of vitamin D deficiency amongst South African men and women aged 25-45 years compared with groups from Ghana, Jamaica and Seychelles. Many factors, including skin pigmentation, sun exposure, sex and low dietary intake, are known to be associated with the vitamin D status. In South Africa, the country with the largest proportion of people living with HIV, along with the largest antiretroviral therapy (ART) programme, the prevalence of vitamin D deficiency may be even worse because of the known relationship between HIV infection and vitamin D status., ${ }^{9,10,11}$

In South Africa, a total of 7.5 million people were reported to be living with HIV in 2019. This makes South Africa a country with the highest burden of HIV infection in the world, with a prevalence rate of $19.0 \%$, in the age group 15 to 49 years. ${ }^{12}$ Furthermore, South Africa has the largest HIV treatment programme, with 3.9 million people initiated on ART in $2016 .{ }^{13} \mathrm{HIV}$ management strategies coupled with the use of ART have shifted the trends of HIV from an inevitably fatal disease to a chronic 
infection. ${ }^{14}$ Chronic HIV infection and exposure to ART are associated with altered vitamin $\mathrm{D}$ metabolism, decreased bone mineral density (BMD) and increased fracture risk. ${ }^{15,16,17} \mathrm{~A}$ longitudinal study in postmenopausal women showed that women living with HIV had greater rates of bone loss at the spine and forearm than HIV-negative postmenopausal women. ${ }^{18}$ Body composition alteration (lipodystrophy) is a common phenomenon in people living with HIV ${ }^{19}$ Furthermore, body composition is an important factor that influences vitamin D status directly or indirectly through interactions with other factors, such as age, sex, skin pigmentation, menopausal status, chronic diseases and medications. ${ }^{20}$ An inverse correlation has been established between vitamin $\mathrm{D}$ status and adiposity in adults. $^{21,22}$ Low- and middle-income countries including South Africa, are experiencing nutrition-related non-communicable diseases resulting from nutrition transition and consequent body composition changes towards increased adiposity. ${ }^{23}$ The South African National Health and Nutrition Examination Survey-1 (SANHANES-1) of 2012 and the South African Demographic and Health Survey of 2016 confirmed the high rates of overweight and obesity in adult women to be $27 \%$ and $41 \%$, respectively. ${ }^{24,25}$

This research study aimed at contributing knowledge on the association between serum 25-hydroxyvitamin D (25(OH)D) and body composition amongstHIV-infected postmenopausal women. To our knowledge, this is the first study to involve the target population in South Africa, which has an increased risk of both vitamin D deficiency and poor bone health.

The findings from the study can potentially inform treatment and care of HIV-infected postmenopausal women.

\section{Materials and methods Study design, setting and participants}

This was a longitudinal study that used data measured in 2017 at baseline, 1-year (2018) and 2-year follow-up (2019) from a larger prospective bone study at the Centre of Excellence for Nutrition (CEN) at the North-West University in Potchefstroom, South Africa. Study participants were recruited from public outpatient ART clinics. Participants who met the inclusion criteria were invited individually to participate and receive information about the project. Those who accepted were included through consecutive convenience sampling. All measurements were performed at the metabolic unit of the North-West University. Signed informed consent was obtained from all participants.

The study involved South African postmenopausal women living with HIV and already on ART. Most participants were on ART regimen-1 for the duration of the study (tenofovir [TDF], emtricitabine [FTC] and efavirenz [EFV]) as a combined antiretroviral therapy (cART). This sub-study was performed on the available participants from the larger study, which included 120 postmenopausal women. The flowchart of participants shows the number of study participants at each measurement date and reasons for loss to follow-up, as shown in Figure 1.

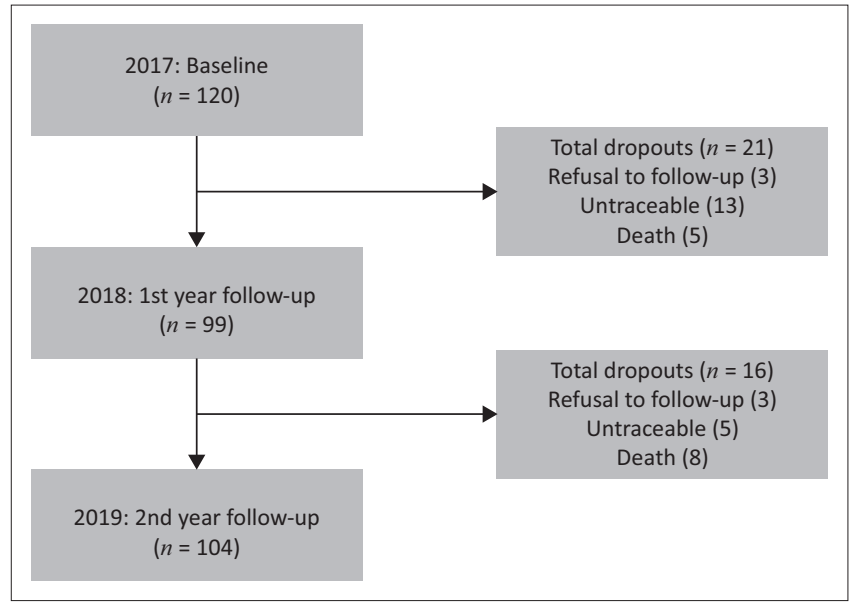

FIGURE 1: Participant flowchart and reasons for loss to follow-up.

A power calculation for the primary analysis of this study (multivariable regression analysis) indicated that a sample size of at least 262 would be necessary at a $\beta$ of 0.4 for the primary exposure, a power of 0.95 and an $\alpha$ of $0.05 .{ }^{26}$ It is therefore possible that the sample size may be too small to show an association even if there was one; however, it was not possible to recruit more women, because most HIV-infected women from these clinics were premenopausal. We therefore analysed and interpreted the available data with caution.

The inclusion criteria included HIV-infected postmenopausal women on ART. 'Postmenopausal' was defined as the selfreported absence of menses for at least 6 months prior to the study. The exclusion criteria included use of anti-osteoporotic agents (corticosteroids, thyroid medication initiated during the previous year, anti-vitamin $\mathrm{K}$ agents, diuretics, antiepileptic drugs and $\beta$-blockers), calcium and vitamin $\mathrm{D}$ supplements, or antacids containing calcium according to their medical records or self-report. Chronic liver disease, chronic obstructive pulmonary disease, chronic renal disease, immobility, rheumatoid arthritis, gastrectomy, malabsorption syndromes, diagnosed diabetes mellitus, history of metabolic bone disease, high alcohol consumption ( $\geq 3$ units/day) and history of a fracture within the last 6 months were also part of the exclusion criteria. Women with severely low BMD at the hip (T-score $<-3$ ) detected at baseline were not enrolled but referred for medical treatment. According to the World Health Organization (WHO), a T-score is the distance in the number of standard deviations from the mean BMD for a young reference group based on data from a white reference population. A T-score of -2.5 and below indicates osteoporosis, and -1.0 to -2.5 indicates osteopenia, whereas a T-score of -1.0 and above represents normal BMD. ${ }^{27}$

\section{Measurements}

\section{Socio-demographic and health information}

Information on participants' socio-demographic and health status was collected using an interviewer-administered structured questionnaire. The following information was captured: age, education level, housing, occupation, smoking, alcohol consumption, chronic medication use (including 
ART), year of first HIV diagnosis and year of ART initiation. All women brought their medication along to the study site to be recorded.

\section{Anthropometric measurements}

Anthropometric measurements included height and weight, and were performed by trained postgraduate Nutrition and Dietetics students. The measurements were conducted on participants without shoes and with minimal clothing. Weight and height were measured using a calibrated digital scale and attached stadiometer (Seca 264, Hamburg, Germany), following standard procedures. ${ }^{28}$ Body mass index (BMI) was calculated by dividing weight in kilograms by height in metres squared. BMI cut-off points were $<18.5$ for underweight, 18.5 to $<25$ for normal weight, 25.0 to $<30$ for overweight and $\geq 30 \mathrm{~kg} / \mathrm{m}^{2}$ for obesity.

Physical activity: Physical activity was assessed by a trained fieldworker using the Global Physical Activity questionnaire (GPAQ) recommended by the WHO. ${ }^{29}$ The questionnaire gathered information on physical activity performed during the previous 7 days in the following occupation: physical activity, transport-related physical activity and physical activity during leisure time. The time spent during the various physical activity domains in terms of frequency (days per week) and duration (minutes per day) was estimated.

Bone mineral density, lean mass and fat mass: Bone mineral density, lean mass and fat mass were measured at all three time points by a registered radiographer using dual-energy X-ray absorptiometry (DXA) with the default Hologic settings (Hologic Discovery W, APEX system software version 2.3.1). BMD at total body, lumbar spine and left femoral neck (FN) of the hip was measured in $\mathrm{g} / \mathrm{cm}^{2}$. Participants were asked to remove all jewellery and were provided with cotton gowns without any metal trimmings to wear during the DXA measurement.

Serum vitamin D and parathyroid hormone concentration: Fasting blood samples of $5 \mathrm{~mL}$ were collected in serum tubes by a registered nurse, were centrifuged immediately and stored in a bio-freezer at $-80{ }^{\circ} \mathrm{C}$ until samples of all the study participants were collected. Serum $25(\mathrm{OH}) \mathrm{D}$ and parathyroid hormone $(\mathrm{PTH})$ were measured by electrochemiluminescence (Cobas e411, Roche, Basel, Switzerland). Samples collected for each time point were analysed together in one batch with the same controls.

Dietary data: Dietary intakes were assessed at baseline and at 1-year follow-up visits in 2018 by trained fieldworkers using a validated quantitative food frequency questionnaire, food models and a validated food picture book to estimate portion sizes. ${ }^{30,31}$ Portion sizes, reported in household measures, were converted to weights. Energy and nutrient intakes (i.e. protein, fat, vitamin D and calcium) were calculated using food finder software based on the South African food composition database. ${ }^{32}$

\section{Statistical analysis}

The distribution of the continuous variables was assessed by histograms, QQ plots and the Kolmogorov-Smirnov test. Descriptive statistics of socio-demographic data, physical activity, BMD at different sites, lean and fat mass, as well as serum 25(OH)D and PTH are presented as means and standard deviation (s.d.) for variables following a normal distribution or median and interquartile range (IQR) for non-normally distributed data. The percentage of participants with vitamin $\mathrm{D}$ deficiency and insufficiency were determined, where vitamin D deficiency was defined as serum $25(\mathrm{OH}) \mathrm{D}$ level $<20 \mathrm{ng} / \mathrm{mL}(50 \mathrm{nmol} / \mathrm{L})$ and insufficiency as $20 \mathrm{ng} / \mathrm{mL}-$ $29 \mathrm{ng} / \mathrm{mL}(50 \mathrm{nmol} / \mathrm{L}-74 \mathrm{nmol} / \mathrm{L})$ according to the Endocrine Society and International Osteoporosis Foundation cut-offs. ${ }^{33}$

Pearson's correlation coefficient (for data with a normal distribution) or Spearman's rank order correlation coefficient (for data with a non-normal distribution) was calculated to examine the correlation between serum 25(OH)D and fat mass, lean mass and whole-body BMD, spine BMD and left FN of the hip BMD, as well as possible covariates (age, alcohol intake, calcium intake, physical activity level and number of years since the HIV diagnosis). Age correlated significantly with several variables and, therefore, Pearson partial correlation with adjustment for age was also performed. Variables with a significant correlation were entered in the linear mixed models (LMMs). Variables with a non-normal distribution were logarithmically transformed before they were entered in the LMM. Differences in exposure and outcomes between groups (smokers compared with non-smokers) were assessed using the Mann-Whitney test, because most variables had a non-normal distribution.

Linear mixed models were used with fat mass, lean mass and $\mathrm{BMD}$, respectively, as the dependent variables (outcomes) and serum $25(\mathrm{OH}) \mathrm{D}$ as the primary exposure, with adjustment for variables identified to correlate with the exposure or outcomes (age, alcohol intake, calcium intake, and physical activity level). These models were also used with BMD as the dependent variable (outcome) and fat mass as well as lean mass as primary exposure, with adjustment for variables identified to correlate with the exposure or outcomes (age, alcohol intake, calcium intake and physical activity level). Separate models were used for whole-body $B M D$, spine BMD and left FN of the hip BMD. Time was treated as a fixed effect and participant as a random effect. The restricted maximum likelihood (REML) estimation method was used, and an unstructured covariance structure was specified.

An adapted version of Cohen's d is used to indicate the practical significance of the differences between the means. The original formula for Cohen's $\mathrm{d}$ for analysis of variance (ANOVA) is as follows:

$d=\frac{\left|\bar{x}_{i}-\bar{x}_{j}\right|}{\sqrt{M S E}}$, 
where $d$ denotes effect size, $\dot{x}_{\mathrm{i}}$ and $\dot{x}_{\mathrm{j}}$ are means of two samples and MSE is the mean standard error. ${ }^{34}$ In this case, however, the estimated marginal means, calculated as part of the LMM analyses, are used and the MSE is replaced by the sum of the covariance estimates. The interpretation guidelines indicate a small effect or practical non-significant $d$ at an effect size of 0.2 , an effect size of 0.5 indicates a medium effect or practical visible difference and an effect size of 0.8 indicates a large effect or practical significant difference. Statistical Package for Social Sciences (SPSS) software, version 26 (IBM Company, Armonk, New York, United States) was used for all analyses.

\section{Ethical considerations}

The study was approved by the Health Research Ethics Committee of the North-West University (Project: NWU00061-17-A1-02).

\section{Results}

The study participants' characteristics are summarised in Table 1. Their median duration of being diagnosed with HIV was 11 years [IQR 7-13 years], and the median duration of using ART was 10 years (IQR 5-13 years). Most participants (approximately 85\%) remained on ART regimen 1 (TDF, FTC, and EFV) as a cART during the 2 years of observation. Combined vitamin D deficiency and insufficiency was estimated to be $29.7 \%$ at baseline, $42.9 \%$ at year 1 and $49.0 \%$ at year 2 of follow-up. Serum PTH concentrations showed an increased trend over time. Only a small proportion of study participants $(10 \%)$ were current smokers, with a median of 2 (IQR 1-4) cigarettes per day. Only five $(4.2 \%)$ participants were previous smokers. The median intake of calcium and vitamin D in the study participants was lower than the recommended dietary intake for women, 51-70 years old, of $1200 \mathrm{mg} / \mathrm{d}$ and $15 \mathrm{mcg} / \mathrm{d}$, respectively. ${ }^{35}$

Table 2 shows correlations between continuous variables according to the distribution of data. Serum 25(OH)D did not correlate with any of the BMD outcomes or total percent fat. Total percent body fat reported a moderate positive correlation with total spine BMD $(r=0.319 ; P<0.0001)$ and left hip FN BMD $(r=0.408 ; P<0.0001)$; however, it had a weak positive correlation with total $\mathrm{BMD}(r=0.239 ; P=0.009)$. Lean mass had a weak negative correlation with age $(r=-0.219 ; P=0.016)$ and a strong positive correlation with BMI $(r=0.824 ; P<0.0001)$.

A comparison between body composition outcomes and vitamin $\mathrm{D}$ status of smokers and non-smokers at baseline revealed no difference in total lean mass, total spine BMD, total BMD, total left hip FN BMD, BMI or vitamin D status; the only difference was in total percent body fat $(P=0.032)$. There was no correlation between serum 25(OH)D and PTH at baseline $(r=-0.11, P=0.24)$, after 1 year $(r=-0.16, P=0.12)$ or after 2 years of follow-up $(r=-0.14, P=0.17)$.
Variables with a non-normal distribution that showed significant correlations from the Spearman correlation were $\log$ transformed, and similar correlations were found. New significant correlations that were observed included a weak negative correlation between BMI and serum 25(OH)D $(r=$ -0.189; $P=0.04)$. Furthermore, BMI had moderate positive correlations with total BMD, total spine BMD and left hip FN $\operatorname{BMD}(P<0.0001)$.

Body mass index, however, had a strong correlation with total percent fat $(r=0.841 ; P<0.0001)$. Age displayed a weak inverse correlation with total spine BMD $(r=-0.242 ; P=$ $0.008)$ and a moderate inverse correlation with total BMD $(r=$ -0.400; $P<0.0001)$ and left hip BMD $(r=-0.346 ; P<0.0001)$. Physical activity correlated positively although weakly with total BMD $(r=0.227 ; P=0.014)$ and left hip FN BMD $(r=$ $0.235 ; P=0.011)$.

Lean mass had a moderate positive correlation with total spine BMD $(r=0.473 ; P<0.0001)$, as well as total BMD $(\mathrm{r}=0.429 ; P<0.0001)$, and a strong positive correlation with left hip FN BMD $(r=0.563 ; P<0.0001)$.

These results did not change after adjustment for age, except that the correlation between physical activity and total BMD was no longer significant $(r=0.177 ; P=0.06)$.

\section{Changes of study exposure variable and body composition outcomes over a 2-year period}

The changes were assessed over the three time points of measurements from baseline to 2-year follow-up.

Changes of main exposure and body composition outcomes are presented in Figures 2, 3 and 4. The serum 25(OH)D concentration declined from baseline through to year 2 follow-up $(P<0.0001)$ with an effect size of 0.39 , indicating a practically visible difference. The Bonferroni pairwise comparison showed a significant decline in serum $25(\mathrm{OH}) \mathrm{D}$ concentration from baseline to year 1 follow-up and from baseline to year 2 follow-up. Total BMD increased from baseline to year 1 follow-up, but with practical non-significant difference (effect size $=0.03$ ). Similarly, left hip FN BMD increased over 2 years; however, the difference was practically non-significant (effect size of 0.06). Changes in left hip FN BMD over the 2 years were between baseline and year 2 follow-up and year 1 and year 2 follow-up. There were no significant changes in PTH from baseline over the two years, although there was an increasing trend over time (Table 1). Lean mass had a practically non-significant difference between baseline and year 2 follow-up (effect size 0.02), whereas percent body fat mass had a practically visible difference over the two years (effect size 0.66).

\section{Association between serum vitamin D concentration and body composition over time}

Linear mixed models were used to describe the association between serum $25(\mathrm{OH}) \mathrm{D}$ as the main exposure and body 
TABLE 1: Study participants' characteristics from baseline to 2-year follow-up.

\begin{tabular}{|c|c|c|c|c|c|c|c|c|c|c|c|c|}
\hline \multirow[t]{2}{*}{ Variable } & \multicolumn{4}{|c|}{$\begin{array}{l}\text { Baseline (2017) } \\
\quad(n=120)\end{array}$} & \multicolumn{4}{|c|}{$\begin{array}{l}\text { Year } 1 \text { (2018) } \\
(n=99)\end{array}$} & \multicolumn{4}{|c|}{$\begin{array}{l}\text { Year } 2 \text { (2019) } \\
\quad(n=104)\end{array}$} \\
\hline & Median & IQR & $n$ & $\%$ & Median & IQR & $n$ & $\%$ & Median & IQR & $n$ & $\%$ \\
\hline Age (years) & 50 & $48-55$ & - & - & 51 & $49-56$ & - & - & 52 & $50-57$ & - & - \\
\hline Weight (kg) & 66.6 & $54.1-80.0$ & - & - & 68.1 & $57.9-83.0$ & - & - & 67.6 & $54.8-83.9$ & - & - \\
\hline Height $(\mathrm{cm})$ & 156.6 & 151.5-161.0 & - & - & 157.5 & $152.3-161.5$ & - & - & 156.7 & $151.8-160.4$ & - & - \\
\hline BMI $\left(\mathrm{kg} / \mathrm{m}^{2}\right)$ & 27.1 & $22.4-32.6$ & - & - & 28.4 & $23.5-32.2$ & - & - & 28.3 & $23.0-33.2$ & - & - \\
\hline Underweight $\left(\mathrm{BMI}<18.5 \mathrm{~kg} / \mathrm{m}^{2}\right)$ & - & - & 10 & 8.3 & - & - & 4 & 4.0 & - & - & 7 & 6.73 \\
\hline Normal BMI $\left(18.5 \mathrm{~kg} / \mathrm{m}^{2}-24.9 \mathrm{~kg} / \mathrm{m}^{2}\right)$ & - & - & 37 & 30.8 & - & - & 31 & 31.3 & - & - & 29 & 27.88 \\
\hline Overweight (BMI $25 \mathrm{~kg} / \mathrm{m}^{2}-29.9 \mathrm{~kg} / \mathrm{m}^{2}$ ) & - & - & 27 & 22.5 & - & - & 23 & 23.2 & - & - & 26 & 25.00 \\
\hline Obese $\left(\mathrm{BMI}>30 \mathrm{~kg} / \mathrm{m}^{2}\right)$ of the total & - & - & 46 & 38.3 & - & - & 41 & 41.4 & - & - & 42 & 40.38 \\
\hline Waist circumference $(\mathrm{cm})$ & 85.0 & $76.0-97.3$ & - & - & 88.6 & $76.9-96.6$ & - & - & 90.8 & 76.7-101.0 & - & - \\
\hline Calf circumference (cm) & 33.9 & $30.0-37.5$ & - & - & 34.4 & $30.7-37.6$ & - & - & $\begin{array}{c}33.9 \\
30.2-37.7\end{array}$ & & - & - \\
\hline Total BMD $\left(\mathrm{g} / \mathrm{cm}^{2}\right)$ & 1.04 & $0.95-1.12$ & - & - & 1.04 & $0.98-1.14$ & - & - & 1.03 & $0.96-1.11$ & - & - \\
\hline Spine BMD $\left(\mathrm{g} / \mathrm{cm}^{2}\right)$ & 0.84 & $0.75-0.95$ & - & - & 0.88 & $0.79-0.98$ & - & - & 0.87 & $0.78-0.97$ & - & - \\
\hline Lean mass (kg) & 37.0 & $32.9-42.6$ & - & - & 38.5 & $33.8-45.2$ & - & - & 37.7 & $34.0-45.6$ & - & - \\
\hline Percent body fat & 38.6 & $33.8-43.6$ & - & - & 39.1 & $33.3-42.8$ & - & - & 39.9 & $33.4-43.6$ & - & - \\
\hline $\begin{array}{l}\text { Serum } 25(\mathrm{OH}) \mathrm{D}(\mathrm{ng} / \mathrm{mL}) \\
\text { (deficiency }<20 \mathrm{ng} / \mathrm{mL} \text { ) }\end{array}$ & 36.6 & $28.1-44.2$ & - & - & 31.5 & $25.0-41.1$ & - & - & 30.1 & $24.9-37.6$ & - & - \\
\hline $\begin{array}{l}\text { Parathyroid hormone }(\mathrm{pg} / \mathrm{mL} \text { ) } \\
\text { (normal range } 10-55 \mathrm{pg} / \mathrm{mL} \text { ) }\end{array}$ & 41.3 & $34.8-58.2$ & - & - & 42.5 & $31.5-56.9$ & - & - & 47.0 & $36.8-61.8$ & - & - \\
\hline $\begin{array}{l}\text { Calcium intake (mg/day) } \\
\text { (recommended intake: } 1200 \mathrm{mg} / \text { day) }\end{array}$ & 668.3 & 413.2-911.9 & - & - & 517.6 & $352.3-794.1$ & - & - & - & - & - & - \\
\hline $\begin{array}{l}\text { Vitamin D intake (mcg/day) } \\
\text { (recommended intake: } 15 \mathrm{mcg} / \text { day) }\end{array}$ & 4.99 & $3.09-6.78$ & - & - & 4.44 & $2.53-7.80$ & - & - & - & - & - & - \\
\hline $\begin{array}{l}\text { Energy intake }(\mathrm{kJ} / \text { day) } \\
\text { (average energy allowance: } 7980 \mathrm{~kJ} / \text { day) }\end{array}$ & 10247 & $7680-12514$ & - & - & 9330 & $6166-11247$ & - & - & - & - & - & - \\
\hline $\begin{array}{l}\text { Fat intake (g/day) } \\
\text { (recommended intake: } 42-74 \text { g/day) }\end{array}$ & 76.6 & $50.0-100.0$ & - & - & 57.1 & $44.5-84.2$ & - & - & - & - & - & - \\
\hline $\begin{array}{l}\text { Protein intake (g/day) } \\
\text { (recommended intake: } 46 \mathrm{~g} / \text { day) }\end{array}$ & 75.6 & $57.1-93.6$ & & & 68.9 & $51.0-96.5$ & - & - & - & - & - & - \\
\hline Alcohol intake (g/day) & 0.0 & $0.0-0.86$ & - & - & 0.0 & $0.0-1.3$ & - & - & - & - & - & - \\
\hline Vitamin D status $\dagger$ & - & - & - & - & & - & - & - & - & - & - & - \\
\hline Deficiency & - & - & 12 & 10.2 & - & - & 14 & 14.3 & - & - & 12 & 11.50 \\
\hline Insufficiency & - & - & 23 & 19.5 & - & - & 28 & 28.6 & - & - & 39 & 37.50 \\
\hline Sufficiency & - & - & 83 & 70.3 & - & - & 56 & 57.1 & - & - & 53 & 51.00 \\
\hline Education & - & & & - & - & & & - & & - & & \\
\hline No school/primary school & - & - & 44 & 36.7 & - & - & 29 & 29.3 & - & - & 31 & 29.80 \\
\hline Grade 8-11 & - & - & 44 & 36.7 & - & - & 40 & 40.4 & - & - & 43 & 41.30 \\
\hline Grade 12 & - & - & 31 & 25.8 & - & - & 29 & 29.3 & - & - & 29 & 27.90 \\
\hline Tertiary & - & - & 1 & 0.8 & - & - & 1 & 1.0 & - & - & 1 & 1.00 \\
\hline Income (per month) & - & - & & & - & - & & & & - & & \\
\hline None & - & & 6 & 5 & - & & 3 & 3 & - & & 10 & 9.60 \\
\hline$<$ R500.00 - R1000.00 & - & - & 31 & 25.8 & - & - & 21 & 21.2 & - & - & 15 & 14.40 \\
\hline R1001.00 - R6000.00 & - & - & 74 & 61.7 & - & - & 64 & 64.6 & - & - & 72 & 69.20 \\
\hline$>$ R6000.00 & - & - & 9 & 7.5 & - & - & 11 & 11.1 & - & - & 7 & 6.70 \\
\hline Hypertension & - & - & 55 & 45.8 & - & - & 46 & 46.5 & - & - & 48 & 46.20 \\
\hline
\end{tabular}

$\mathrm{BMI}$, body mass index; BMD, bone mineral density; FN, femoral neck; Ca, calcium; IQR, interquartile range; MET, metabolic equivalent; PA, physical activity; 25(OH)D, 25 hydroxyvitamin D.

$\dagger$, Participant numbers vary because of missing values for some biochemical values.

TABLE 2: Correlation between serum vitamin D, lifestyle, health and body composition variables: Pearson's correlation between serum vitamin D and body composition variables.

\begin{tabular}{|c|c|c|c|c|c|c|c|c|}
\hline \multirow[t]{2}{*}{ Variable } & \multicolumn{2}{|c|}{ Total spine BMD } & \multicolumn{2}{|c|}{ Left hip BMD } & \multicolumn{2}{|c|}{ Total BMD } & \multicolumn{2}{|c|}{ Total percent age fat } \\
\hline & $r$ & $P$ & $r$ & $P$ & $r$ & $P$ & $r$ & $P$ \\
\hline $\begin{array}{l}\text { Serum vitamin D } \\
\text { (ng/mL) }\end{array}$ & -0.003 & 0.970 & 0.001 & 0.990 & 0.000 & 0.999 & -0.072 & 0.437 \\
\hline Percent body fat $(\%)$ & 0.319 & $<0.0001$ & 0.408 & $<0.0001$ & 0.239 & 0.009 & - & - \\
\hline
\end{tabular}

BMD, bone mineral density.

composition outcomes that included percent body fat, lean mass (logarithmically transformed), total BMD, lumbar spine BMD and left hip FN BMD. Associations between body composition components (fat mass, lean mass and BMD) were also determined by LMMs. Estimates of the associations were adjusted for education level, household income, age, physical activity, duration of ART and alcohol intake as potential confounders. Table 3 presents the associations. All 
models showed an improvement in goodness of fit after adding covariates to the crude models, as demonstrated by the Schwarz Bayesian information criterion (BIC).

The model with the lowest BIC was selected as the best model.

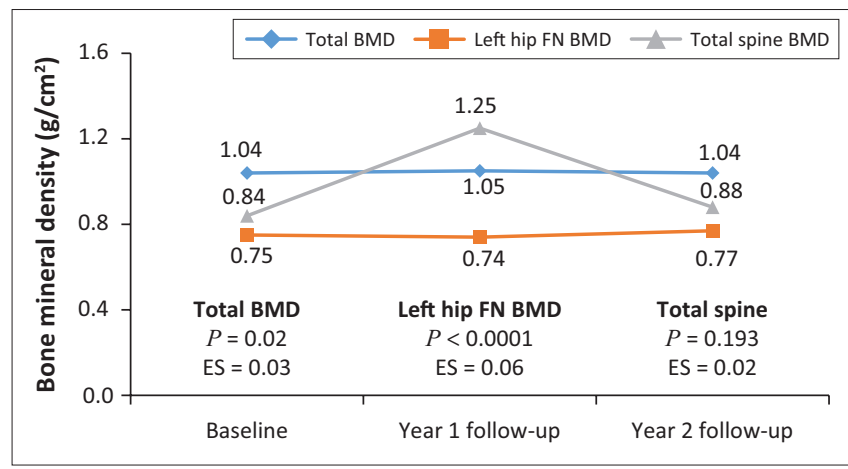

$B M D$, bone mineral density; $E S$, effect size; FN, femur neck.

FIGURE 2: Bone mineral density changes over 2 years from baseline.

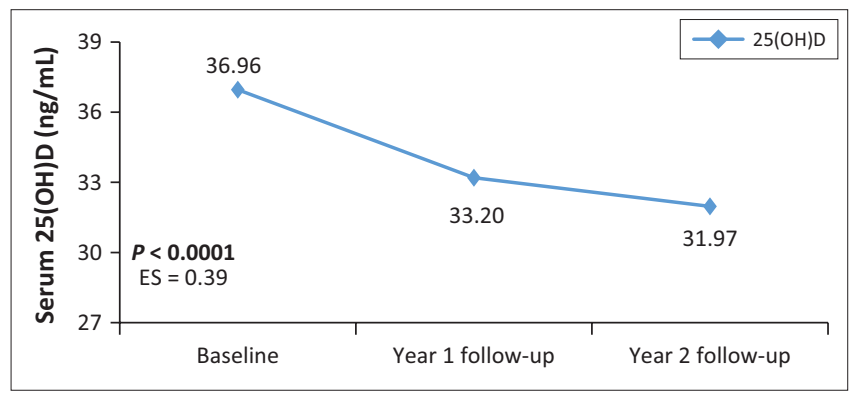

ES, effect size; 25(OH)D, 25-hydroxyvitamin D.

FIGURE 3: Serum 25-hydroxyvitamin D changes over 2 years from baseline.

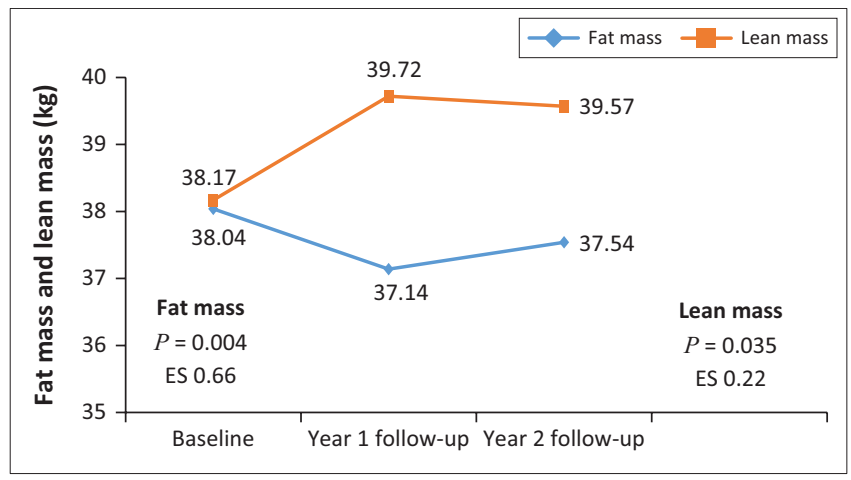

$E S=$ effect size.

FIGURE 4: Lean and fat mass changes over 2 years from baseline.
Serum 25(OH)D was neither associated with any of the three BMD outcomes, nor with percent body fat or lean mass. However, serum $25(\mathrm{OH}) \mathrm{D}$ showed a significant association with BMI in the unadjusted model $(P=0.024)$; however, there was no significant association after adjusting for education level, household income, age, physical activity and alcohol intake. There was a positive association between physical activity and left hip FN BMD. Age was consistently inversely associated with all body composition outcomes. Both percent fat mass and lean mass were associated with left hip FN BMD and total BMD, but not with total spine BMD (Table 4).

\section{Discussion}

This 2-year longitudinal study focused on investigating the association between serum 25(OH)D and body composition (lean mass, fat mass and BMD) in South African postmenopausal women living with HIV and on ART. According to the Endocrine Society and International Osteoporosis Foundation cut-offs for vitamin D status by Valcour et al., ${ }^{33}$ serum 25(OH)D insufficiency (deficiency and insufficiency) increased from $29.7 \%$ at baseline to $49.0 \%$ at year 2 of follow-up. Despite a significant decrease in serum $25(\mathrm{OH}) \mathrm{D}$ over time, there were practically no changes in BMD over the 2 years. There was no association between serum 25(OH)D concentration and total BMD, spine BMD, left hip FN BMD, lean mass or \%BF consistently throughout the study period. From the LMMs on the interdependent associations between body composition components, lean mass and fat mass showed positive associations with total BMD and left hip FN BMD but not with total spine BMD. Lean mass proved to be stronger predictor of BMD than fat mass.

The study findings on vitamin D status (insufficiency and deficiency prevalence) correspond with those from some observational studies amongst postmenopausal women populations. ${ }^{36,37,38}$ Kuchuk et al. ${ }^{39}$ reported similar serum $25(\mathrm{OH}) \mathrm{D}$ deficiency levels in both summer and winter amongst postmenopausal women from 29 countries across the world. Serum $25(\mathrm{OH}) \mathrm{D}$ concentrations also declined during the 2-year study period in the Dallas Heart Study on a multi-ethnic adult population in Dallas, Texas, United States. ${ }^{40}$

TABLE 3: Correlation between serum vitamin D, lifestyle, health and body composition variables: Spearman's correlations between lifestyle, demographic variables and body composition.

\begin{tabular}{|c|c|c|c|c|c|c|c|c|c|c|}
\hline \multirow[t]{2}{*}{ Variable } & \multicolumn{2}{|c|}{ Lean mass } & \multicolumn{2}{|c|}{$\begin{array}{l}\text { Total physical activity MET } \\
\text { (min/week) }\end{array}$} & \multicolumn{2}{|c|}{ HIV duration (years) } & \multicolumn{2}{|c|}{ Duration of ART use } & \multicolumn{2}{|c|}{ Ca intake } \\
\hline & $r$ & $P$ & $r$ & $P$ & $r$ & $P$ & $r$ & $P$ & $r$ & $P$ \\
\hline Age (years) & $-0.219 *$ & 0.016 & -0.062 & 0.503 & -0.042 & 0.648 & -0.014 & 0.883 & -0.016 & 0.864 \\
\hline $\begin{array}{l}\text { Physical activity (MET } \\
\mathrm{min} / \text { week) }\end{array}$ & 0.147 & 0.108 & - & - & -0.012 & 0.899 & -0.051 & 0.578 & 0.004 & 0.966 \\
\hline HIV duration (years) & 0.032 & 0.731 & -0.012 & 0.899 & - & - & $0.856 * *$ & $<0.0001$ & -0.083 & 0.368 \\
\hline $\begin{array}{l}\text { Duration of ART use } \\
\text { (years) }\end{array}$ & -0.038 & 0.684 & -0.051 & 0.578 & $0.856 * *$ & $<0.0001$ & - & - & -0.131 & 0.157 \\
\hline
\end{tabular}

ART, antiretroviral therapy; $\mathrm{BMI}$, body mass index; MET, metabolic equivalent.

*, significant correlation, $P<0.05 ; * *$, significant correlation, $P<0.01$. 
TABLE 4: Association between serum vitamin $D$ and body composition and interdependent associations between body composition variables.

\begin{tabular}{|c|c|c|c|c|c|c|c|c|c|c|}
\hline \multirow[t]{2}{*}{ Variable } & \multicolumn{2}{|c|}{ Total BMD } & \multicolumn{2}{|c|}{ Total spine BMD } & \multicolumn{2}{|c|}{ Left hip FN BMD } & \multicolumn{2}{|c|}{ Percentage body fat } & \multicolumn{2}{|c|}{ Lean mass } \\
\hline & $\begin{array}{l}\text { Mean } \\
\text { estimate }\end{array}$ & $P$ & $\begin{array}{c}\text { Mean } \\
\text { estimate }\end{array}$ & $P$ & $\begin{array}{c}\text { Mean } \\
\text { estimate }\end{array}$ & $P$ & $\begin{array}{l}\text { Mean } \\
\text { estimate }\end{array}$ & $\boldsymbol{P}$ & $\begin{array}{l}\text { Mean } \\
\text { estimate }\end{array}$ & $\boldsymbol{P}$ \\
\hline \multicolumn{11}{|l|}{$\begin{array}{l}\text { Association between serum } \\
\text { vitamin } \mathrm{D} \text { and body composition }\end{array}$} \\
\hline Age (years) & -0.009 & $<0.0001$ & 0.068 & 0.031 & -0.008 & $<0.0001$ & -0.105 & 0.406 & -0.004 & 0.032 \\
\hline Education level & 0.021 & 0.836 & 0.137 & 0.467 & -0.006 & 0.585 & - & - & - & - \\
\hline Household income & 0.005 & 0.519 & 0.125 & 0.364 & 0.020 & 0.010 & - & - & - & - \\
\hline Alcohol intake (g) & 0.001 & 0.415 & -0.006 & 0.820 & -0.0001 & 0.894 & -0.004 & 0.943 & 0.0008 & 0.573 \\
\hline Physical activity (MET min/week) & 0.032 & 0.067 & -0.118 & 0.708 & 0.041 & 0.021 & 0.558 & 0.323 & 0.0001 & 0.994 \\
\hline Serum $25(\mathrm{OH}) \mathrm{D}(\mathrm{ng} / \mathrm{mL})$ & -0.951 & 0.886 & -0.003 & 0.784 & -8.20 & 0.904 & -0.035 & 0.404 & -0.001 & 0.131 \\
\hline \multicolumn{11}{|c|}{ Interdependent associations between $\% \mathrm{BF}$, lean mass and $\mathrm{BMD}$} \\
\hline Age (years) & -0.009 & $<0.0001$ & - & - & - & - & - & - & - & - \\
\hline Education level & -0.001 & 0.898 & 0.141 & 0.440 & -0.009 & 0.299 & - & & - & - \\
\hline Household income & 0.005 & 0.496 & 0.125 & 0.353 & 0.021 & 0.003 & - & & - & - \\
\hline Alcohol intake (g) & 0.001 & 0.359 & -0.007 & 0.772 & -2.609 & 0.984 & - & & - & - \\
\hline Physical activity (MET min/week) & 0.027 & 0.112 & -0.072 & 0.817 & 0.029 & 0.070 & - & & - & - \\
\hline Percent body fat (\%) & 0.003 & 0.004 & -0.031 & 0.147 & 0.006 & $<0.0001$ & - & & - & - \\
\hline \multicolumn{11}{|c|}{ Interdependent association between lean mass and BMD } \\
\hline Age (years) & -0.008 & $<0.0001$ & 0.067 & 0.032 & -0.007 & $<0.0001$ & - & & - & - \\
\hline Education level & 0.001 & 0.911 & 0.128 & 0.487 & -0.006 & 0.541 & - & & - & - \\
\hline Household income & 0.005 & 0.511 & 0.127 & 0.349 & 0.020 & 0.005 & - & & - & - \\
\hline Duration of ART (years) & -0.001 & 0.530 & 0.020 & 0.528 & -0.001 & 0.451 & - & & - & - \\
\hline Alcohol intake (g/day) & 0.001 & 0.399 & -0.006 & 0.807 & -0.0002 & 0.857 & - & & - & - \\
\hline Physical activity (MET min/week) & 0.033 & 0.051 & -0.128 & 0.682 & 0.041 & 0.016 & - & & - & - \\
\hline Lean mass (kg) & 0.256 & 0.001 & -0.258 & 0.854 & 0.301 & $<0.0001$ & - & & - & - \\
\hline
\end{tabular}

$A R T$, antiretroviral therapy; $B M D$, bone mineral density; $F N$, femoral neck; $M E T$, metabolic equivalent.

Vitamin D is primarily known for an association with BMD via the homeostasis of calcium and phosphate. ${ }^{41}$

There was no association observed between serum 25(OH)D and total BMD, left hip FN BMD and total spine BMD over a follow-up period of two years. The study findings are in agreement with a number of studies, including randomised controlled trials (RCTs) with vitamin D supplementation. ${ }^{42,43}$ A cross-sectional study by Kamineni et al. ${ }^{44}$ in India amongst postmenopausal women revealed findings similar to this study, where no correlation was observed between serum 25(OH)D and BMD. However, a cross-sectional study amongst Chinese postmenopausal women found positive correlations between serum 25(OH)D and BMD outcomes at lumbar spine, total hip and FN. ${ }^{45}$ Differences between the findings of these studies and the current study could be partially explained by differences in menopause duration, duration of sunlight exposure amongst the women, genetic factors and ethnicity. ${ }^{4}$

Study observation period is likely another plausible reason for the lack of association between serum 25(OH) and BMD. Changes in BMD take a long time to manifest and, hence, the duration could have been inadequate to detect noticeable significant changes in this study. Hamill et al. ${ }^{46}$ observed a cohort of urban black HIV-infected South African premenopausal women over a period of 24 months. A significant finding was the attenuation of bone mass loss beyond 12 months up to 24 months in the HIV-infected group on ART. Although the participants were premenopausal women, this signifies that bone loss in HIV-infected patients within the first 12 months on ART could be transient. Our study's participants showed a small, but significant, BMD increase at left FN BMD and total BMD, but no change at total spine BMD. Other authors had suggested a follow-up longer than 24 months to ascertain BMD changes. ${ }^{46}$ This study's participants had an average ART use duration of 9 years, which might explain BMD stabilisation. Information about previous ART regimens could not be determined; however, it is likely that most women received first-line ART regimens at the public outpatient clinics and could have been switched to the present first-line regimen (TDF, FTC, EFV) soon after these fixed dose combinations became available in 2013. ${ }^{47}$ Therefore, most women have been exposed to TDF for three years or longer.

Despite the lack of association between serum 25(OH)D and BMD, we reported a decline in serum $25(\mathrm{OH}) \mathrm{D}$ levels from baseline to two years; however, the effect size was relatively small. This decrease may be related to the HIV status of the women. A high prevalence of vitamin D deficiency has been described amongst HIV-infected patients. ${ }^{10}$ The inflammatory processes associated with HIV infection and ART metabolism both alter vitamin $\mathrm{D}$ metabolism and may have been associated with the decline in serum 25(OH)D levels during the observation period. ${ }^{48}$

Very low serum 25(OH)D concentrations trigger PTH surge, which leads to bone demineralisation as a compensatory measure to maintain balance in serum calcium. ${ }^{49}$ The decline in serum $25(\mathrm{OH}) \mathrm{D}$ concentrations probably explains the 
small, although non-significant, progressive increase in PTH, which was probably insufficient to lead to a decline in BMD. In agreement with this study's findings, Kota et al..$^{50}$ reported no direct association between serum 25(OH)D and BMD. However, they found a stronger inverse association with serum $25(\mathrm{OH}) \mathrm{D}$ and $\mathrm{PTH}$, indicating that low serum $25(\mathrm{OH}) \mathrm{D}$ level was indirectly associated with low BMD. Contrary findings to ours were reported in a 12-months longitudinal study amongst urban black South African premenopausal women. An increase in serum $25(\mathrm{OH}) \mathrm{D}$ regardless of the HIV status was reported over 12 months..$^{51}$ The obvious difference between the two studies is age of the participants, where the study participants were postmenopausal women (mean age: 50 years), whereas the other study included premenopausal women.

Aging is a known risk factor for hypovitaminosis D through decreased vitamin $\mathrm{D}$ receptors and consequent alteration of vitamin $\mathrm{D}$ metabolism. ${ }^{52}$ We also found a non-significant inverse correlation between serum $25(\mathrm{OH}) \mathrm{D}$ concentration and age. A longitudinal study in Amsterdam reported a small decline in serum $25(\mathrm{OH}) \mathrm{D}$ levels in older participants (65-88 years) over 13 years, which is in agreement with the study findings. ${ }^{53}$ Poopedi et al. ${ }^{54}$ affirmed progressive fluctuations in serum $25(\mathrm{OH}) \mathrm{D}$ levels in a study amongst healthy adolescents over 10 years. These progressive changes in serum $25(\mathrm{OH}) \mathrm{D}$ levels observed in longitudinal studies, as well as this study, signify that single measurements are unreliable for determining associations between serum $25(\mathrm{OH}) \mathrm{D}$ and diseases.

This study reported no association between serum 25(OH)D and percent body fat or lean mass; however, there was a weak negative correlation with BMI. In agreement with this finding, there is a recent cross-sectional study amongst postmenopausal women, which reported an inverse correlation between serum 25(OH)D and anthropometric measurements, including BMI. ${ }^{55} \mathrm{BMI}$ is used as a proxy for adiposity, and the sequestration theory provides a probable explanation for the inverse association displayed between body fat and serum $25(\mathrm{OH}) \mathrm{D} .{ }^{56}$

In a cross-sectional study, however, $\mathrm{Li}$ et al. ${ }^{45}$ reported no association between BMI and serum 25(OH)D in Chinese postmenopausal women. The authors argued that their result was based on the unique body composition of the Chinese women, characterised by a lower prevalence of obesity than in other ethnic groups. This emphasises the role of ethnicity in the interaction between serum 25(OH)D and body composition. The study participants had a relatively high prevalence rate of overweight and obesity, which is in the range of $22.5 \%-25.7 \%$ and $38.3 \%-40.0 \%$, respectively, over two years.

Previous observational studies have described other known determinants of BMD; however, the relative contribution of lean mass and fat mass to BMD remains a contentious subject. The data of this study showed that both lean mass and percent fat mass were positively associated with left hip FN
$\mathrm{BMD}$ and total BMD, but not with total spine BMD. However, lean mass was a stronger predictor of BMD than fat mass. This result is a replication of findings from other observational studies amongst postmenopausal women. ${ }^{57,58,59}$ Similarly, a systematic review by Ho-Pham et al ${ }^{60}$ proved lean mass to be a stronger determinant of BMD compared with fat mass. This signifies that the interdependent interactions between body composition components can be influenced by menopause status. The association between fat mass and BMD is probably mediated by the increased load placed on the skeleton, whereas lean mass influences BMD through increased mechanical stress mediated by muscle on the skeleton. Both mediators act as stimuli for osteogenesis. ${ }^{61,62}$

A significant proportion of the women in this study were overweight (22.5\% and $25.7 \%$ at baseline and 2-year followup, respectively) and obese (38.3\% at baseline and $40.0 \%$ at 2-year follow-up). We reported a quite unusual finding of a small, but significant, fat mass decline and lean mass increase in the women during the 2-year study period, in contrast with normal aging changes. ${ }^{57}$ The results of this study revealed a significant positive association between physical activity and left hip FN BMD, the site most prone to fracture in postmenopausal women. Such findings were reported previously in a Canadian retrospective study amongst postmenopausal women. ${ }^{63}$

Apart from serum 25(OH)D concentration, known risk factors for low BMD, such as dark skin, HIV, ART and advanced age (postmenopausal status), were present in the study participants. Physical activity levels were relatively good, signifying probable adequate exposure to sunlight and adequate stimuli to maintaining bone health. We further reported low exposure to lifestyle risk activities such as smoking and alcohol intake. These factors may further explain the small decrease in serum $25(\mathrm{OH}) \mathrm{D}$ levels and the preserved BMD over a follow-up period of two years. Diet is another known modifiable risk factor for optimal bone health, with the value of specific nutrients, such as dietary calcium and vitamin D, well established. ${ }^{64}$

The dietary calcium and vitamin D intake of participants were relatively low compared with dietary recommendations (1200 mg and $15 \mathrm{mcg}$, respectively, per day). ${ }^{35}$ These results are in line with those of previous studies amongst South African women. ${ }^{65}$ Foods are poor sources of vitamin D. Therefore, most of the daily input of vitamin D comes from cutaneous synthesis rather than from diet. ${ }^{64}$ In countries where foods are fortified with vitamin $\mathrm{D}$, these foods are the major dietary source of vitamin $\mathrm{D}^{64}$; however, few foods are enriched with vitamin D in South Africa. ${ }^{65}$

\section{Recommendations}

Urbanisation of black South African women may increase the risk of low bone mass because of low vitamin D status, low calcium intake and high bone turnover. ${ }^{65}$ Hence, there is a need for advising women on the intake of vitamin D and calcium. As the largest source of vitamin D is through 
cutaneous synthesis, an increase in outdoor activities and exposure to the sun may help to improve the vitamin D status.

\section{Limitations and strengths}

Limitations and strengths existed in this study that need to be acknowledged. Firstly, this study used an observational design with limited control over other potential covariates, and no HIV-negative reference group was included. Secondly, all participants originated from the same locality in the North West province of South Africa and, therefore, generalisation of the findings to a wider population across South Africa and beyond should be performed cautiously. Thirdly, the sample size was relatively small, thereby undermining the power for subgroup analysis, that is, subgroups based on the vitamin D status. It was challenging to recruit more participants, because most HIV-infected women from the outpatient clinics were premenopausal. The findings of no statistically significant associations could, therefore, be because of type II error, and a larger sample could potentially have yielded a different result.

Regarding strengths, to the best of our knowledge, this is the first longitudinal study on an association between serum 25(OH)D and body composition in South African postmenopausal women living with HIV and on ART in South Africa. A longitudinal design provides stronger evidence of probable associations when compared with a cross-sectional study design. Future studies should consider all determinants of serum $25(\mathrm{OH}) \mathrm{D}$ concentration and body composition, such as duration of sunlight exposure, as well as dietary assessment over a longer duration.

\section{Conclusion}

This 2-year longitudinal study indicates no association between serum $25(\mathrm{OH}) \mathrm{D}$ concentration and BMD over time. However, BMI was inversely associated with serum $25(\mathrm{OH})$ $\mathrm{D}$ concentration. In terms of the relative contribution of lean mass and fat mass to maintenance of BMD, lean mass is a stronger determinant of BMD than fat mass. South African postmenopausal women living with HIV and on ART maintained their BMD at all three sites over a period of two years. The study further suggests that BMD decreased with increasing age, whilst physical activity was protective against a decrease in BMD in this group of women. The results of this study may inform strategies to prevent fractures in postmenopausal women living with HIV. Increasing lean mass through physical activity could be important to preventing frailty and morbidity in this vulnerable group.

\section{Acknowledgements}

The authors acknowledge the assistance of registered nurses, Ms C.M. Lessing and Ms A. Anthony, who acted as study coordinators and assisted with the blood sample collection. Ms G. Wood performed language editing of the manuscript. Postdoctoral associate Dr Patricia Ukegbu and postgraduate students Shams Bakali, Phillip Buys and Persuade Makore assisted with study coordination and data collection.

\section{Competing interests}

The authors declare that they have no financial or personal relationships, which may have inappropriately influenced them in writing this article.

\section{Authors' contributions}

S.M., MSc student, and C.E., PhD student, collected data, drafted the manuscript and analysed the data. J.C. contributed to the manuscript preparation and participated in data collection. M.C. supervised statistical analysis and approved the final version of the manuscript. C.M.C.M. supervised biochemical analyses and approved the final version of the manuscript. H.S.K. conceptualised the study, supervised data collection and quality control, interpreted the data and approved the final version of the article.

\section{Funding information}

The authors acknowledge financial support from the Support for Nutrition Research in Africa (SUNReA), the Sugar Association of South Africa, Massey University, New Zealand, and the South African National Research Foundation (NRF TWAS programme) [UID 1055500]. The funders were not involved in any aspect of the design, implementation, analysis, or interpretation and write-up of the study. Any opinion, findings and conclusion or recommendation expressed in this article is that of the authors, and the NRF does not accept any liability in this regard.

\section{Data availability}

No data are available from publicly available data sets; however, data will be made available after approval from the Health Research Ethics Committee, North-West University, if requested by reviewers or editors after submission to a scientific journal.

\section{Disclaimer}

The views and opinions expressed in this article are those of the authors and do not necessarily reflect the official policy or position of any affiliated agency of the authors.

\section{References}

1. Carmeliet G, Dermauw V, Bouillon R. Vitamin $D$ signaling in calcium and bone homeostasis: A delicate balance. Best Pract Res Clin Endocrinol Metab. 2015;29(4):621-631. https://doi.org/10.1016/j.beem.2015.06.001

2. Bouillon R, Carmeliet G. Vitamin D insufficiency: Definition, diagnosis and management. Best Pract Res Clin Endocrinol Metab. 2018;32(5):669-684. https:// doi.org/org/10.1016/j.beem.2018.09.014

3. Wang $H$, Chen $W$, Li $D$, et al. Vitamin $D$ and chronic diseases. Aging Dis. 2017;8(3):346. https://doi.org/10.14336/AD.2016.1021

4. Mansoor S, Habib A, Ghani F, et al. Prevalence and significance of vitamin D deficiency and insufficiency among apparently healthy adults. Clin Biochem. 2010;43(18):1431-1435. https://doi.org/10.1016/j.clinbiochem.2010.09.022

5. Nair R, Maseeh A. Vitamin D: The "sunshine" vitamin. J Pharmacol Pharmacother. 2012;3(2):118. https://doi.org/10.4103/0976-500X.95506 
6. Palacios C, Gonzalez L. Is vitamin D deficiency a major global public health problem? J Steroid Biochem Mol Biol. 2014;144:138-145. https://doi. org/10.1016/j.jsbmb.2013.11.003

7. Arabi A, El Rassi R, Fuleihan GE-H. Hypovitaminosis D in developing countries Prevalence, risk factors and outcomes. Nat Rev Endocrinol. 2010;6(10):550-561. https://doi.org/10.1038/nrendo.2010.146.

8. Durazo-Arvizu RA, Camacho P, Bovet $P$, et al. 25-Hydroxyvitamin D in African-origin populations at varying latitudes challenges the construct of a physiologic norm. Am J Clin Nutr. 2014;100(3):908-914. https://doi.org/10.3945/ajcn.113.066605

9. Dao $C N$, Patel $P$, Overton ET, et al. Low vitamin D among HIV-infected adults: Prevalence of and risk factors for low vitamin D Levels in a cohort of HIV-infected adults and comparison to prevalence among adults in the US general population. Clin Infect Dis. 2011;52(3):396-405. https://doi.org/10.1093/cid/ciq158

10. Pinzone $M$, Di Rosa $M$, Malaguarnera $M$, et al. Vitamin $D$ deficiency in HIV infection: An underestimated and undertreated epidemic. Eur Rev Med Pharmacol Sci. 2013;17(9):1218-1232.

11. Sherwood JE, Mesner OC, Weintrob AC, et al. Vitamin D deficiency and its association with low bone mineral density, HIV-related factors, hospitalization, and death in a predominantly black HIV-infected cohort. Clin Infect Dis. 2012;55(12):1727-1736. https://doi.org/10.1093/cid/cis785

12. Avert. HIV and AIDS in East and Southern Africa 2019 [homepage on the Internet] [cited 2021 Sept 3] Available from: https://www.avert.org/professionals/hivaround-world/sub-saharan-africa

13. SANAC. South Africans' national strategic plan for HIV, TB and STI 2017-2022. Pretoria: South African National AIDS Council; 2017.

14. Broder $\mathrm{S}$. The development of antiretroviral therapy and its impact on the HIV-1/ AIDS pandemic. Antiviral Res. 2010;85(1):1-18. https://doi.org/10.1016/j. antiviral.2009.10.002

15. Dave JA, Cohen K, Micklesfield LK, Maartens G, Levitt NS. Antiretroviral therapy, especially efavirenz, is associated with low bone mineral density in HIV-infected South Africans. PLoS One. 2015;10(12):e0144286. https://doi.org/10.1371/ journal.pone. 0144286

16. Herrin $M$, Tate JP, Akgün KM, et al. Weight gain and incident diabetes among HIV infected-veterans initiating antiretroviral therapy compared to uninfected individuals. J Acquir Immune Defic Syndr. 2016;73(2):228. https://doi. org/10.1097/QAl.0000000000001071

17. Shiau S, Broun EC, Arpadi SM, Yin MT. Incident fractures in HIV-infected individuals: A systematic review and meta-analysis. AIDS (London, England). 2013;27(12):1949. https://doi.org/10.1097/QAD.0b013e328361d241

18. Yin MT, Zhang CA, McMahon DJ, et al. Higher rates of bone loss in postmenopausal HIV-infected women: A longitudinal study. J Clin Endocrinol Metab. 2012;97(2):554-562. https://doi.org/10.1210/jc.2011-2197

19. Wanke C. Epidemiology, clinical manifestations, and diagnosis of HIV-associated lipodystrophy. UpToDate. Waltham, MA: Walters Kluwer Health; 2016.

20. Tsiaras WG, Weinstock MA. Factors influencing vitamin D status. Acta Derm Venereol. 2011;91(2):115-124. https://doi.org/10.2340/00015555-0980

21. Boonchaya-anant $P$, Holick MF, Apovian CM. Serum 25-hydroxyvitamin D levels and metabolic health status in extremely obese individuals. Obesity. 2014;22(12):2539-2543. https://doi.org/10.1002/oby.20877

22. Vimaleswaran KS, Berry DJ, Lu C, et al. Causal relationship between obesity and vitamin D status: Bi-directional Mendelian randomization analysis of multiple cohorts. PLoS Med. 2013;10(2):e1001383. https://doi.org/10.1371/journal. pmed.1001383

23. Vorster $\mathrm{HH}$, Kruger A, Margetts BM. The nutrition transition in Africa: Can it be steered into a more positive direction? Nutrients. 2011;3(4):429-441. https://doi. org/10.3390/nu3040429

24. National Department of Health. The DHS Program Demographic and Health Survey 2016 [homepage on the Internet] [cited 2021 Sept 3]. Available from: https://dhsprogram.com/publications/publication-fr337-dhs-final-reports.cfm

25. Shisana O, Labadarios D, Rehle T, et al. The South African National Health and Nutrition Examination Survey, 2012: SANHANES-1: The health and nutritional status of the nation [homepage on the Internet]. 2014 [cited 2021 Sept 3] Available from: http://hdl.handle.net/20.500.11910/2864

26. Faul F, Erdfelder E, Buchner A, Lang A-G. Statistical power analyses using G* Power 3.1: Tests for correlation and regression analyses. Behav Res Methods. 2009;41(4):1149-1160. https://doi.org/10.3758/BRM.41.4.1149

27. World Health Organisation. Assessment of fracture risk and its application to screening for postmenopausal osteoporosis: Report of a WHO study group [meeting held in Rome from 22 to 25 June 1992]. Geneva: World Health Imeeting held in Rom

28. Lee RD, Nieman DC. Nutritional assessment. New York, NY: McGraw-Hill; 2013.

29. WHO. Global Physical Activity Questionnaire (GPAQ) Analysis Guide 2017 [homepage on the Internet] [cited 2021 Sept 3]. Available from: https://www. who.int/ncds/surveillance/steps/resources/GPAQ_Analysis_Guide.pdf

30. Venter C, MacIntyre $U$, Vorster $\mathrm{H}$. The development and testing of a food portion photograph book for use in an African population. J Hum Nutr Diet. 2000;13(3):205-218. https://doi.org/10.1046/j.1365-277x.2000.00228.x

31. Wentzel-Viljoen E, Kruger A, Laubscher R. Using different approaches to assess the reproducibility of a culturally sensitive quantified food frequency questionnaire. S Afr J Clin Nutr. 2011;24(3):143-148. https://doi.org/10.1080/160 70658.2011.11734366

32. Wolmarans P, Danster N, Dalton A, Rossouw K, Schönfeldt H. Condensed food composition tables for South Africa. Cape Town: Medical Research Council; 2010; p. 1-126.
33. Valcour A, Blocki F, Hawkins D, Rao SD. Effects of age and serum 25-OH-vitamin D on serum parathyroid hormone levels. I Clin Endocrinol Metab. 2012.97(11):39893895. https://doi.org/10.1210/jc.2012-2276

34. Cohen J. Quantitative methods in psychology: A power primer. Psychol Bull. 1992;112(1):155-159. https://doi.org/10.1037//0033-2909.112.1.155

35. Institute of Medicine. Dietary reference intakes for calcium and vitamin D. Washington, DC: National Academies Press; 2011.

36. Chutterpaul P, Paruk F, Cassim B. Prevalence of vitamin D deficiency in older South Africans with and without hip fractures and the effects of age, body weight, ethnicity and functional status. J Endocrinol Metabol Diab S Afr. 2019;24(1):1015. https://doi.org/10.1080/16089677.2018.1534360

37. Tindall AM, Schall JI, Seme B, et al. Vitamin D status, nutrition and growth in HIVinfected mothers and HIV-exposed infants and children in Botswana. PLOS One. 2020;15(8):e0236510. https://doi.org/10.1371/journal.pone.0236510

38. White Z, White S, Dalvie T, Kruger MC, Van Zyl A, Becker P. Bone health, body composition, and vitamin D status of black preadolescent children in South Africa. Nutrients. 2019;11(6):1243. https://doi.org/10.3390/nu11061243

39. Kuchuk NO, Van Schoor NM, Pluijm SM, Chines A, Lips P. Vitamin D status, parathyroid function, bone turnover, and BMD in postmenopausal women with osteoporosis: Global perspective. J Bone Miner Res. 2009;24(4):693-701. https:// doi.org/10.1359/jbmr.081209

40. Mirfakhraee S, Ayers CR, McGuire DK, Maalouf NM. Longitudinal changes in serum 25-hydroxyvitamin D in the Dallas Heart Study. Clin Endocrinol (Oxf). 2017;87(3):242-248. https://doi.org/10.1111/cen.13374

41. Blaine J, Chonchol M, Levi M. Renal control of calcium, phosphate, and magnesium homeostasis. Clin J Am Soc Nephrol. 2015;10(7):1257-1272. https://doi. org/10.2215/CJN.09750913

42. Aloia J, Fazzari M, Islam S, et al. Vitamin D supplementation in elderly black women does not prevent bone loss: A randomized controlled trial. J Bone Min Res. 2018;33(11):1916-1922. https://doi.org/10.1002/jbmr.3521

43. Aspray TJ, Chadwick T, Francis RM, et al. Randomized controlled trial of vitamin D supplementation in older people to optimize bone health. Am J Clin Nutr. 2019;109(1):207-217. https://doi.org/10.1093/ajcn/nqy280

44. Kamineni V, Latha AP, Ramathulasi K. Association between serum 25-hydroxyvitamin D levels and bone mineral density in normal postmenopausal women. J Midlife Health. 2016;7(4):163. https://doi.org/10.4103/0976-7800.195694

45. Li S, Ou Y, Zhang $H$, et al. Vitamin $D$ status and its relationship with body composition, bone mineral density and fracture risk in urban central south Chinese postmenopausal women. Ann Nutr Metab. 2014;64(1):13-19. https:// doi.org/10.1159/000358340.

46. Hamill MM, Pettifor JM, Ward KA, Norris SA, Prentice A. Bone mineral density, body composition, and mineral homeostasis over 24 months in urban South African women with HIV exposed to antiretroviral therapy. J Bone Min Res Plus. 2020;4(5):e10343. https://doi.org/10.1002/jbm4.10343

47. Davies NECG. Fixed-dose combination for adults accessing antiretroviral therapy: Advice document. S Afr J HIV Med. 2013;14(1):41-43. https://doi.org/10.7196/ SAJHIVMED.913

48. Childs K, Welz T, Samarawickrama A, Post FA. Effects of vitamin D deficiency and combination antiretroviral therapy on bone in HIV-positive patients. AIDS. 2012;26(3):253-262. https://doi.org/10.1097/QAD.0b013e32834f324b.

49. Ardawi M-S, Sibiany A, Bakhsh T, Qari M, Maimani A. High prevalence of vitamin D deficiency among healthy Saudi Arabian men: Relationship to bone minera density, parathyroid hormone, bone turnover markers, and lifestyle factors. Osteoporos Int. 2012;23(2):675-686. https://doi.org/10.1007/s00198-011-1606-1

50. Kota SK, Jammula S, Kota S, Meher L, Modi K. Correlation of vitamin D, bone mineral density and parathyroid hormone levels in adults with low bone density. Indian J Orthop. 2013;47(4):402-407. https://doi.org/10.4103/0019-5413.114932

51. Hamill MM, Pettifor JM, Ward KA, Norris SA, Prentice A. Changes in bone minera density, body composition, vitamin D status, and mineral metabolism in urban HIV-positive South African women over 12 months. I Bone Min Res. 2017;32(8):1615-1624. https://doi.org/10.1002/jbmr.3147

52. De Jongh RT, Van Schoor NM, Lips P. Changes in vitamin D endocrinology during aging in adults. Mol Cell Endocrinol. 2017;453:144-150. https://doi.org/10.1016/j. mce.2017.06.005

53. Van Schoor N, Knol D, Deeg D, Peters F, Heijboer A, Lips P. Longitudinal changes and seasonal variations in serum 25 -hydroxyvitamin $D$ levels in different age groups: Results of the Longitudinal Aging Study Amsterdam. Osteoporos Int. 2014;25(5):1483-1491. https://doi.org/10.1007/s00198-014-2651-3

54. Poopedi MA, Norris SA, Micklesfield LK, Pettifor JM. Does vitamin D status track through adolescence? Am J Clin Nutr. 2015;102(5):1025-1029. https://doi. org/10.3945/ajcn.115.112714

55. Vázquez-Lorente H, Molina-López J, Herrera-Quintana L, Gamarra-Morales $Y$ López-González B, Planells E. Association between body fatness and vitamin D3 status in a postmenopausal population. Nutrients. 2020;12(3):667. https://doi. org/10.3390/nu12030667

56. Rosenstreich SJ, Rich C, Volwiler W. Deposition in and release of vitamin D 3 from body fat: Evidence for a storage site in the rat. J Clin Invest. 1971;50(3):679-687. https://doi.org/10.1172/JCl106538

57. Chen $Y$, Xiang J, Wang $Z$, et al. Associations of bone mineral density with lean mass, fat mass, and dietary patterns in postmenopausal Chinese women: A 2-year prospective study. PLoS One. 2015;10(9):e0137097. https://doi.org/10.1371/ journal.pone.0137097

58. Ilesanmi-Oyelere BL, Coad J, Roy N, Kruger MC. Lean body mass in the prediction of bone mineral density in postmenopausal women. Biores Ope Access. 2018;7(1):150-158. https://doi.org/10.1089/biores.2018.0025 
59. Sotunde $\mathrm{O}$, Kruger $\mathrm{H}$, Wright $\mathrm{HH}$, et al. Lean mass appears to be more strongly associated with bone health than fat mass in urban black South African women. J Nut Health Aging. 2015;19(6):628-636. https://doi.org/10.1007/s12603-015-0492-1

60. Ho-Pham LT, Nguyen UD, Nguyen TV. Association between lean mass, fat mass, and bone mineral density: A meta-analysis. J Clin Endocrinol Metab. 2014;99(1):30-38. https://doi.org/10.1210/jc.2013-3190

61. Kelley GA, Kelley KS, Kohrt WM. Exercise and bone mineral density in premenopausal women: A meta-analysis of randomized controlled
Endocrinol. 2013;2013:741639. https://doi.org/10.1155/2013/741639

62. Zhang $Z$, Shen $X$, Zhang $H$, et al. The relationship between body composition and fracture risk using the FRAX model in central south $C$ hinese postmenopausa women. Clin Endocrinol (Oxf). 2012;77(4):524-530. https://doi.org/10.1111/ j.1365-2265.2012.04399.x
63. Muir JM, Ye C, Bhandari M, Adachi JD, Thabane L. The effect of regular physical activity on bone mineral density in post-menopausal women aged 75 and over: A retrospective analysis from the Canadian multicentre osteoporosis study. BMC Musculoskelet Disord. 2013;14(1):1-9. https://doi.org/10.1186/1471 2474-14-253

64. Bonjour J-P, Guéguen L, Palacios C, Shearer MJ, Weaver CM. Minerals and vitamins in bone health: The potential value of dietary enhancement. $\mathrm{Br} J$ Nutr 2009;101(11):1581-1596. https://doi.org/10.1017/S0007114509311721.

65. Kruger MC, Kruger IM, Wentzel-Viljoen E, Kruger A. Urbanization of black South African women may increase risk of low bone mass due to low vitamin $D$ status, low calcium intake, and high bone turnover. Nutr Res. 2011;31(10):748-758. https://doi.org/10.1016/j.nutres.2011.09.012. 